\title{
Calanoid copepods and nutrient enrichment determine population dynamics of the appendicularian Oikopleura dioica: a mesocosm experiment
}

\author{
Herwig Stibor ${ }^{1, *}$, Olav Vadstein ${ }^{2}$, Bettina Lippert ${ }^{1}$, Wendy Roederer $^{1}$, Yngvar Olsen $^{3}$ \\ ${ }^{1}$ Department Biologie II, Abteilung Aquatische Ökologie, Universität München, Karlstraße 23-25, 80333 München, Germany \\ ${ }^{2}$ Department of Biotechnology, and ${ }^{3}$ Trondhjem Biological Station, Norwegian University of Science and Technology, \\ 7491 Trondheim, Norway
}

\begin{abstract}
Appendicularians, an important group of marine gelatinous zooplankton, are highly efficient filter feeders of small phyto- and bacterioplankton. It is not known which factors regulate their abundance and biomass in the field. In a mesocosm experiment, we manipulated nutrient loading and initial densities of calanoid copepods (almost exclusively the genera Temora sp., Centropages and Pseudocalanus) and followed plankton dynamics over 2 wk. Peak appendicularian densities were inversely related to initial copepod densities. We observed more than 100 -fold variation in Oikopleura dioica density among treatments, even though our experimental variables were kept within ecologically relevant magnitudes. The differences between copepod-reduced and copepodenhanced treatments were much larger at high and moderate nutrient loadings than in treatments without nutrient enrichment. Thus, appendicularians are under strong pressure from calanoid copepods. Calanoid copepods appear to structure the plankton community via direct negative effects on large algae, ciliates and appendicularians and indirect positive effects on small algae resulting from the release of these from predation by ciliates and appendicularians.
\end{abstract}

KEY WORDS: Oikopleura $\cdot$ Appendicularia $\cdot$ Calanoid copepods $\cdot$ Top-down regulation $\cdot$ Mesocosms Omnivory

\section{INTRODUCTION}

In general, 3 main functional groups may be present in the so called 'herbivorous' zooplankton of marine pelagic systems. The first group is small unicellular predators such as ciliates or flagellates which have high maximum growth rates, short generation times in the range of days, and feed on small $(<20 \mu \mathrm{m})$ nanoand picoplankton (Gismervik et al. 1996, Hansen et al. 1997, Perez et al. 1997). The second group is calanoid copepods, which have a preference for larger particles $(>20 \mu \mathrm{m})$ such as microphytoplankton and ciliates (Paffenhöfer \& Knowles 1980, Kleppel 1993, Fessenden \& Cowles 1994, Sommer et al. 2000). The third group is gelatinous filter-feeders such as appendicularians, salps and doliolids, which have a potentially large food size spectrum but show a clear preference for small particles $<20 \mu \mathrm{m}$ (Flood et al. 1992, Sommer et al. 2000). Compared to calanoid copepods, which have generation times of several weeks or more in temperate waters, appendicularians have much shorter generation times, on the order of several days (Uye \& Ichino 1995). Ciliates and appendicularians may therefore show much quicker population responses to sudden increases in algal production. Thus, while the population dynamics of algae and ciliates and of algae and appendicularians may exhibit a tight predator-prey coupling, algae may temporarily outgrow copepods.

Appendicularians are ubiquitous in the marine zooplankton. They filter their food with highly effective fil- 
tration structures (Deibel \& Powell 1987, Acuna 2001). In recent years, appendicularians have gained the deserved attention of marine biologists for several reasons. First, because of their efficient grazing of small particles (Flood et al. 1992) they constitute an important link between bacterial and picoalgal production and higher trophic levels (Cushing 1989). This pathway of energy transfer up the food chain is more direct than that through heterotrophic flagellates and ciliates. Second, their highly specialized morphology and life-history allow appendicularians to live in environments with low abundance of food not accessible to other large metazoan herbivores (Acuna 2001). Third, their production of mucoid 'filter houses' can be responsible for a large part of particulate carbon sedimentation during appendicularian blooms (Alldredge 1976).

Suggestions about factors regulating appendicularian abundances include phytoplankton blooms (Valentin et al. 1987, Nakamura 1998), water temperature (Acuna \& Anadon 1992) and predation by fish larvae (Shelbourne 1962, Ryland 1964, Nakamura 1998), yet only limited data exist to evaluate these suggestions. Appendicularian abundances often fluctuate (Landry et al. 1994). However, in some regions they can sometimes represent the most abundant metazoan zooplankton group (Deibel 1998), a position normally held by calanoid copepods. Food size could be an important factor determining the success of copepods and appendicularians. Their preferences for differently sized food particles result in low food size overlap between copepods and appendicularians (Sommer et al. 2000). Therefore, the size distribution of the phytoplankton community could be an important factor influencing their relative abundances (Sommer \& Stibor 2002). In addition to these bottom-up-related hypotheses, top-down processes are only rarely considered to be important in structuring marine pelagic food webs (Verity \& Smetacek 1996). Recently, however, it became evident that copepods can have strong predatory effects on ciliate populations (Stoecker \& Capuzzo 1990, Kleppel 1993, Pierce \& Turner 1995) which, in turn, may indirectly influence algal community structure since small algae would thus be released from grazing pressure by ciliates.

In previous field mesocosm experiments we have observed an inverse relationship between copepod and appendicularian abundances (H. Stibor unpubl. data). We therefore hypothesized that copepods may not only influence ciliate numbers but also appendicularian abundances. To investigate this question in detail we conducted a mesocosm experiment in a sheltered bay on the coast of Norway. The experiment was designed to test the influence of copepod abundance on the structure and dynamics of lower trophic levels in the pelagic food web. To broaden the generality of our results, both copepod and nutrient loads were manipulated within natural ranges.

\section{MATERIALS AND METHODS}

The experiment was arranged as a $3 \times 3$ factorial experiment, with mesozooplankton (calanoid copepod) density as one factor and nutrient loading as the second factor. The experiment was carried out during August-September 2000 in the landlocked coastal bay Hopavågen $\left(63^{\circ} 36^{\prime} \mathrm{N}, 9^{\circ} 33^{\prime} \mathrm{E}\right)$, west of Trondheim, central Norway (for details about the bay of Hopavågen see van Marion 1996). We moored 9 mesocosms made from transparent polyethylene tubes to floating stands. The volume of each bag was approximatelx $5 \mathrm{~m}^{3}$, with a diameter of $0.9 \mathrm{~m}$ and a total depth of $6.5 \mathrm{~m}$, consisting of a $6 \mathrm{~m}$ straight tube and a sealed, conical bottom. We filled the mesocosms on the evening before the start of the experiment (Day 0) by lifting them from ca. $7 \mathrm{~m}$ depth to the surface. The water columns in the bags did not stratify and were well mixed by wave action. We assigned 3 mesocosms to each of 3 copepod treatments: reduced density (removal of calanoid copepods by means of vertical hauls with a $200 \mu \mathrm{m}$ plankton net), ambient density, and enhanced density (addition of calanoid copepods carefully collected by net hauls in Hopavågen). The calanoid copepod community consisted of Temora longicornis, Centropages sp., Pseudocalanus elongatus and Acartia longiremis. More than two-thirds of the biomass was copepods of the genera Temora and Pseudocalanus, which were fairly equal in biomass. In addition, the cyclopoid copepod Oithona similis was present in all mesocosms. Its density was approximately the same in all treatments and was always below 5 individuals (ind.) $\mathrm{l}^{-1}$. Non-crustacean zooplankton consisted mainly of bivalve veliger larvae and polychaetes (Tomopteris sp.); it never exceeded 4 ind. $\mathrm{I}^{-1}$ and did not show major changes in abundance or composition during the experiment (Lippert 2001).

We added nutrients to the mesocosms on the evening of Day 1 and each of the 11 evenings thereafter. Each mesozooplankton treatment was cross-classified with 3 different nutrient regimes: no addition, normal, and high addition. The normal regime was comparable to the natural load of the system (Vadstein et al. 2004, this volume). We added nutrients in an atomic ratio of 16:16:1 for Si:N:P. Si was in the form of silicate, P of phosphate, and $\mathrm{N}$ of nitrate and ammonia (1:1). The daily $\mathrm{P}$ additions were $0,0.5$ and $2.5 \mu \mathrm{g} \mathrm{P}^{-1} \mathrm{~d}^{-1}$. Background levels of dissolved inorganic nutrients were close to detection limit for $\mathrm{Si}$ and $\mathrm{N}$ and between 3 and $5 \mu \mathrm{g} \mathrm{l}^{-1}$ for P. 
We sampled the entire water column of each enclosure every $3 \mathrm{~d}$ between 07:00 and 08:00 h with an opaque tube sampler covered with black plastic to protect the plankton from light exposure (length $2 \mathrm{~m}$, diameter $0.12 \mathrm{~m}$; Ramberg 1976). Zero to $6 \mathrm{~m}$ depthintegrated water samples (25 l) were transferred to low-transparency bottles. We used $21 \mathrm{l}$ from each sample to collect the mesozooplankton, which we concentrated on a $35 \mu \mathrm{m}$ net, transferred to a $250 \mathrm{ml}$ plastic vial, and fixed with acid Lugol's iodine to a final concentration of $1 \%$. Subsamples for analysis of chlorophyll a were taken from the remaining water. We filtered these through a $200 \mu \mathrm{m}$ net and collected the samples on Whatman GF/F glass-fiber filters. The filters were extracted in methanol, and chlorophyll $a$ was quantified by fluorometry using a Turner Designs fluorometer; 2 replicates were analyzed per sample.

Mesozooplankton was identified and counted in a Wild MZ3 dissecting microscope. When copepod/ appendicularian abundances in a sample exceeded 400 individuals we split the sample and analyzed a $50 \%$ sub-sample. Aliquots of copepods and appendicularians were burned in a C-Mat 500 carbon analyzer to determine mesozooplankton biomass.

\section{RESULTS}

Our manipulations of copepod numbers in the different experimental treatments were effective (Fig. 1A). Differences in the means of the initial copepod densities between treatments with reduced, ambient and enhanced copepod densities were significant (KruskalWallis test, $H=6.5$ with $2 \mathrm{df}, \mathrm{p}=0.011$. A pairwise multiple comparison procedure (Student-Newman-Keuls) resulted in significant differences between ambient and enhanced copepod treatments and reduced and enhanced copepod treatments.

Copepod numbers and the composition of the copepod community did not change in a significant way during the experiment (Fig. 2 and Lippert 2001).

Nutrient additions also had distinct effects. Chlorophyll a levels at the start of the experiment were about $3 \mu \mathrm{g}$ chlorophyll a $\mathrm{l}^{-1}$. At the end of the experiment levels ranged between 2.3 and $14.6 \mu \mathrm{g}$ chlorophyll a $\mathrm{l}^{-1}$ (Fig. 1B). The differences in mean chlorophyll a levels between different nutrient addition regimes were significant (ANOVA, $F_{(2,6)}=82.7 ; \mathrm{p}<0.001$ ). A pairwise multiple comparison procedure (Tukey's) resulted in significant differences between normal and high nutrient loading and zero and high nutrient loading. Chlorophyll dynamics were similar in bags with the same nutrient regime (Fig. 2).

In all mesocosms, appendicularian abundances were near or below the detection limit on Day 1
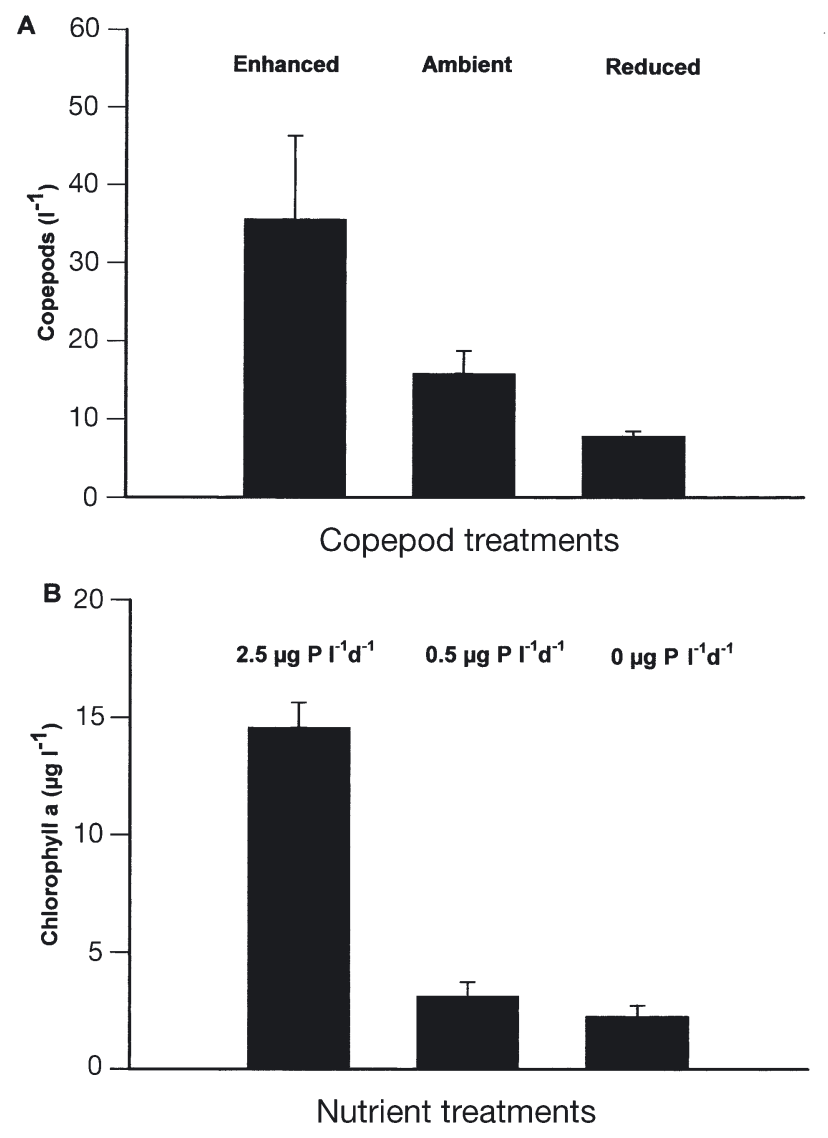

Fig. 1. (A) Copepod numbers as a function of initial abundance; (B) chlorophyll levels as a function of nutrient load; chlorophyll a levels in each mesocosm on Days 10 and 12 were averaged and treated as single mean. Error bars $=\mathrm{SE}$

(Fig. 2). In bags with reduced initial copepod abundances, appendicularians (exclusively the species Oikopleura dioica) started to increase about $7 \mathrm{~d}$ into the experiment. This fits well with reported generation times of approximately $1 \mathrm{wk}$ for $O$. dioica (Uye \& Ichino 1995). In the bags with reduced initial copepod abundances, $O$. dioica abundance peaked on Days 10 to 12 , when $O$. dioica accounted for 20 to $70 \%$ of total zooplankton abundance, depending on the nutrient load. The bags receiving normal and high nutrient additions reached peak $O$. dioica densities of about 65 ind. $\mathrm{l}^{-1}$ on Day 12, whereas in the bag without nutrient addition $O$. dioica peaked at only about 20 ind. $1^{-1}$ on Day 10 (Fig. 2)

In enclosures with ambient initial densities of calanoid copepods, Oikopleura dioica densities remained low (mostly $<5$ ind. $\mathrm{l}^{-1}$ throughout the experiment (Fig. 2) After $12 \mathrm{~d}$ the proportion of $O$. dioica was between 10 and $30 \%$ of total zooplanton abundance (Fig. 2). In enclosures with high initial densities of calanoid copepods and high nutrient addition, O. dioica never accounted for more than $10 \%$ of total 


\section{Reduced copepod treatments}
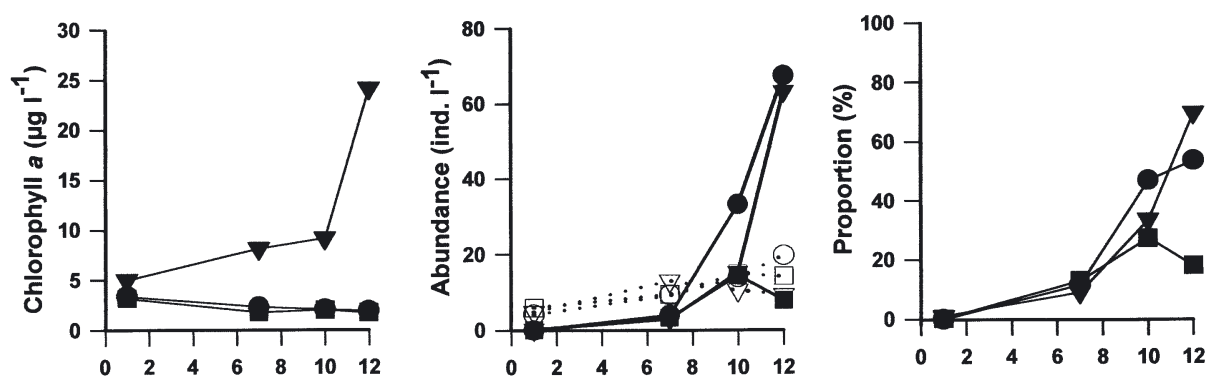

Ambient copepod treatments
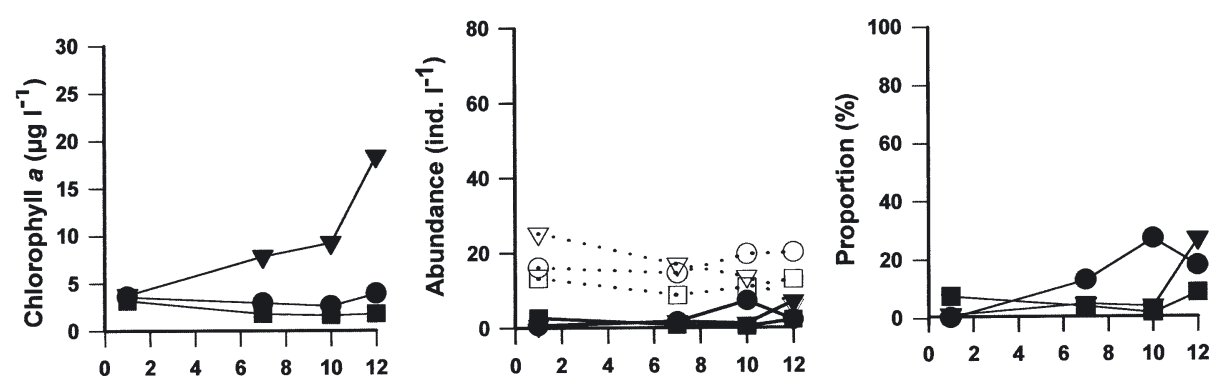

\section{Enhanced copepod treatments}
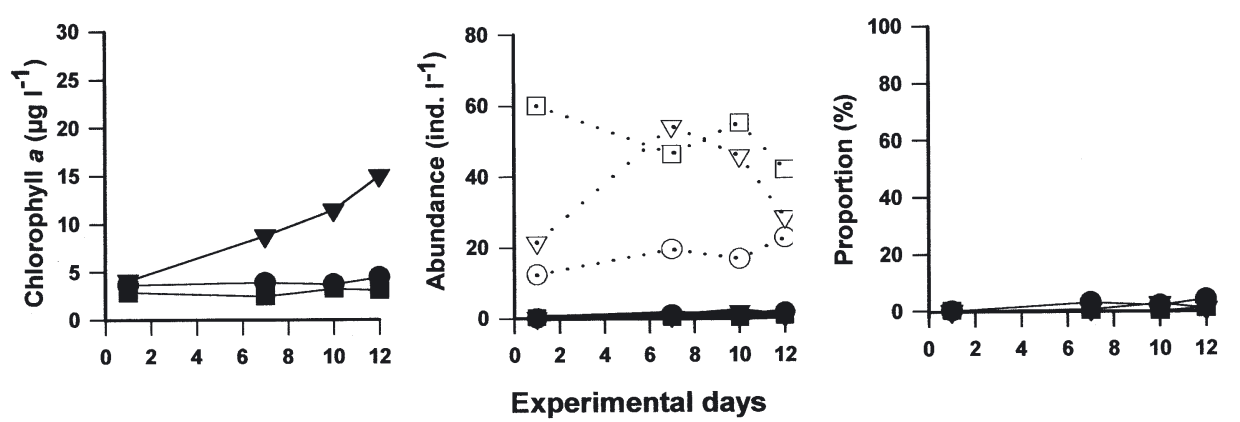

Fig. 2. Dynamics of chlorophyll $a$, calanoid copepods and Oikopleura dioica as a function of nutrient load. ( $\nabla)$ High nutrient load $\left(2.5 \mu \mathrm{molP} \mathrm{l}^{-1} \mathrm{~d}^{-1}\right)_{;}$(@) medium

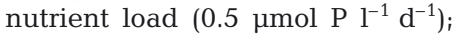
(घ) zero nutrient load. Left-hand graphs: chlorophyll a levels; centre graphs: copepod and O. dioica abundances (filled symbols and continuous lines $=O$. dioica abundances, open symbols and dotted lines = copepod abundances); right-hand graphs: proportion of O. dioica in total zooplankton (\%)

zooplankton numbers (Fig. 2). Its contribution to total zooplankton abundance was even lower $(<5 \%)$ in the bags with moderate and zero nutrient addition. O. dioica numbers were always below 2 ind. $1^{-1}$ (Fig. 2).

The strong negative effect of copepods on Oikopleura dioica toward the end of the experiment was supported by a Kruskal-Wallis analysis of the 3 copepod treatments (Fig. $3 ; H=7.2$ with 2 df, $\mathrm{p}=0.004$ ). A pairwise multiple comparison procedure (StudentNewman-Keuls) resulted in significant differences between all treatments.

A multiple regression revealed a strong, negative effect of copepod biomass and a positive effect of nutrient load on $O$. dioica biomass $\left(\mathrm{r}^{2}=0.978\right.$, $\mathrm{p}<0.001$; Table 1). The tight negative relationship between appendicularian and calanoid copepod biomass is also evident from a simple regression excluding nutrient load (Fig. $4 ; \mathrm{r}^{2}=0.863$, p $<0.001$ ).

\section{DISCUSSION}

In marine systems, research on the factors structuring planktonic food webs has often focussed on the investigation of bottom-up forces such as nutrient supply and food abundance (Verity \& Smetacek 1996). Zooplankton has often only been considered as a passive link between primary production and fish yield. Recently, however, it has become clear that omnivory is a common feature among many zooplankton groups such as protozoans, soft-bodied tunicates (e.g. appendicularians and salps) and calanoid copepods, which were originally thought to be strict herbivores. Numerous evidences of calanoid copepods feeding on ciliates clearly show that predation within the zooplankton should not be neglected (Stoecker \& Capuzzo 1990, Gifford \& Dagg 1991, Kleppel 1993, Pierce \& Turner 1995, Nejstgaard et al. 1997). We have presented strong evidence 


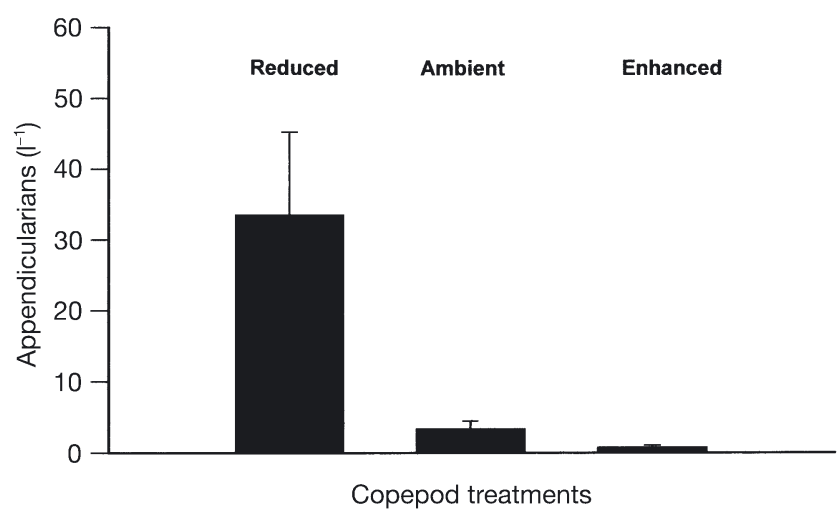

Fig. 3. Oikopleura dioica mean numbers in different copepod treatments. Numbers in each mesocosm from Days 10 and 12 were averaged and treated as a single mean. Error bars $=\mathrm{SE}$

Table 1. Oikopleura dioica. Results of a multiple linear regression of appendicularian biomass on copepod biomass and nutrient load. $A$ : appendicularian biomass $\left(\mu \mathrm{gC} \mathrm{l}^{-1} \mathrm{~d}^{-1}\right)$; $C$ : copepod biomass $\left(\mu \mathrm{C} \mathrm{C}^{-1} \mathrm{~d}^{-1}\right) ; N$ : nutrient loading ( $\mu \mathrm{mol} \mathrm{P}$ $\mathrm{l}^{-1} \mathrm{~d}^{-1}$ ). Appendicularia biomass was log-transformed to ensure homogenity of variances: $\log A=2.770-(0.0542 \times C)+$ $(0.241 \times N) ; \mathrm{r}^{2}=0.978 ;$ ANOVA: $F_{(2,6)}=135.02 ; \mathrm{p}<0.001$

\begin{tabular}{|lcccc|}
\hline & Coefficient & $\mathrm{SD}$ & $t$ & $\mathrm{p}$ \\
\hline Constant & 2.77 & 0.123 & 22.43 & $<0.001$ \\
$\mathrm{C}$ & -0.0542 & 0.003 & -16.20 & $<0.001$ \\
$\mathrm{~N}$ & 0.241 & 0.042 & 5.634 & $<0.01$ \\
\hline
\end{tabular}

that copepods may control appendicularian abundance. This should result in even stronger indirect effects of copepods on small algae, since the latter are the preferred food of both ciliates and appendicularians (Flood et al. 1992, Sommer et al. 2000). Copepods may therefore not only have direct negative effects on large algae, ciliates and appendicularians, but also indirect effects on algal community composition through the suppression of consumers of small algae.

Appendicularians have the potential to attain very fast growth rates (Uye \& Ichino 1995). It is therefore not surprising that their success in the different mesocosms was also determined by nutrient load which stimulated the production of algal food. At zero nutrient loading the increase in appendicularian numbers was not high enough for them to reach dominance in the zooplankton community, even in the reduced copepod treatment, in which appendicularians increased only slightly after the reduction of calanoid copepods, but the increase was not very strong. In the mesocosms receiving moderate and high nutrient enrichment, the increase in appendicularian abundances after copepod removal was several-fold stronger.
Our results indicate that negative effects of calanoid copepods can override the discussed positive effects of nutrients on appendicularian abundance. For example, high-nutrient-addition bags with ambient and enhanced initial calanoid copepod densities had higher chlorophyll concentrations (both total chlorophyll and chlorophyll $<20 \mu \mathrm{m}$ ) during the first days of the experiment (Lippert 2001, Vadstein et al. 2004) than the bag with reduced initial copepod densities. Nevertheless, appendicularian abundances were about 100 times higher in the latter bag at that time.

What are the mechanisms behind the suppression of appendicularians by copepods? One possibility is competition for food. This would mean that food overlap between copepods and appendicularians is larger than previously thought (Sommer et al. 2000). If this possibility is real we would, however, expect some differences among treatments with enhanced copepod numbers but different nutrient loadings. Increasing food levels at constant copepod numbers should alleviate competition, in which case appendicularians should increase. However, appendicularians in the enhanced copepod treatments always stayed below 2 ind. $\mathrm{l}^{-1}$, regardless of the food situation. Clogging of the appendicularian filters at high chlorophyll levels seemed to be of minor importance as appendicularians increased dramatically in high food treatments after the removal of copepods. A second possibility could be predation. As it becomes increasingly clear that calanoid copepods do feed on ciliates, nauplii and other types of animal food, it seems possible that they also feed on appendicularian eggs and larval stages. These stages are in a size range ingestible by calanoid

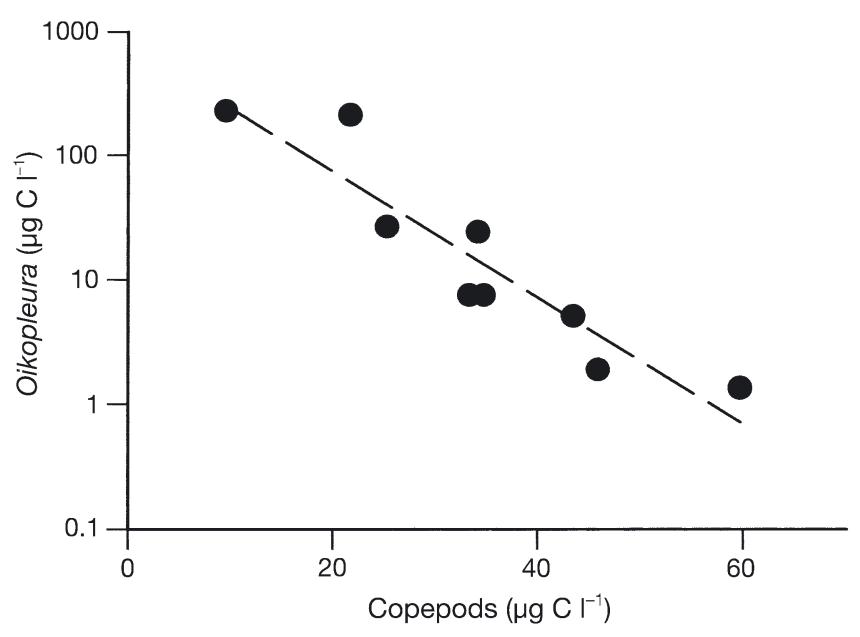

Fig. 4. Oikopleura dioica regression of appendicularian biomass on copepod biomass. Linear regression analysis gave: $\log A=2.895-0.0508 \times C_{i} F_{(1,7)}=44.207 ; \mathrm{p}<0.001$, where $A=$ O. dioica biomass (mean for Days 10 and 12), and $C=$ copepod biomass (mean biomass during experiment) 
copepods (between 40 and $80 \mu \mathrm{m}$ ). Predation on eggs and larval stages could effectively suppress the recruitment of appendicularians. However, until now, copepod predation on appendicularians has only been reported for the carnivorous Candacia bipinnata (Ohtsuka \& Onbe 1989). Predation by copepods could be influenced by food availability. It depends on the selectivity of copepods for appendicularian eggs/larvae and algae or other microplankton food whether high chlorophyll levels (acting as an alternative food source) can form a refuge from predation for appendicularians. Our results show that copepods also suppressed Oikopleura dioica at very high chlorophyll levels. If predation on appendicularian eggs or larvae is the reason for their suppression, high alternative food levels did not offer a refuge from predation.

Inverse relations between the abundances of copepods and appendicularians have also been observed in other studies. King et al. (1980) observed a bloom of Oikopleura dioica (13 and 6 ind. $\mathrm{r}^{-1}$ ) in 2 mesocosms after calanoid copepods declined. A rapid development of Oikopleura sp., reaching densities of about 8 ind. $\mathrm{l}^{-1}$, was also observed in mesocosm experiments with low copepod densities ( $<10$ ind. $^{-1}$; Koshikawa et al. 1999). Finally, a recent mesocosm study also reported a negative correlation between copepod and appendicularian numbers (Sommer et al. 2003). In addition, field data suggest an inverse relationship between copepod and appendicularian numbers. In a time series of Baltic Sea zooplankton, appendicularians reached high numbers (>20 ind. $\mathrm{l}^{-1}$ ) only when copepod numbers dropped below 10 ind. $1^{-1}$ (Behrends 1996). We were able to confirm a negative relationship between appendicularian and calanoid copepods through direct experimental manipulation of copepod numbers in controlled conditions under different nutrient conditions. These experimental manipulations resulted in more than 100-fold differences in appendicularian numbers as a function of high and low copepod abundances in the same nutrient regime.

The observed suppression of appendicularians and ciliates by calanoid copepods confirms a role for copepods as a keystone group in the marine plankton (Stibor et al. 2004). Calanoid copepods can have strong top-down effects on both of the other 2 important functional zooplankton groups (unicellular predators and gelatinous filter-feeders). Hence, calanoid copepods may not only structure the zooplankton community but also the phytoplankton community. Copepods simultaneously promote small pico- and nanoplankton by suppressing their main grazers and decimate larger algae such as diatoms and dinoflagellates by direct grazing.

The increasing evidence for calanoid copepods acting as important structuring components of pelagic food webs should be of some relevance to marine aquaculture. Techniques of harvesting copepods as a natural food resource for fish farming have recently gained attention. Such techniques should take into consideration that - at least on a timescale of $2 \mathrm{wk}-$ zooplankton community composition could shift towards gelatinous forms and ciliates if copepods are reduced below a critical density. The initial copepod numbers in the mesocosms (ca. 8 to 50 ind. $\mathrm{l}^{-1}$ ) was within the normal range observed in Hopavågen during summer for the period 1996-2000 (I. Gismervik unpubl. data). Our data are consistent across the $3 \times 3$ experimental treatment matrix; also, on a short timescale, it has been well documented that the transient responses observed in mesocosms of the size we used are both reproducible and ecologically relevant (Castberg et al. 2001). We therefore claim that in addition to the qualitative conclusions regarding mechanisms, our observations should be directly applicable to natural pelagic communities. From our data, we would consider a density of about 10 copepods $\mathrm{l}^{-1}$ (copepods of the size of Acartia spp. or Temora spp.) a critical level below which appendicularians may bloom. Whether this limit is relevant also for long-term field situations requires additional studies of the copepod-appendicularian interaction on a timescale longer than those normally used in mesocosm experiments.

Acknowledgements. We thank K. Andresen, S. O. Linde, K. Loseth, L. Sundt-Hansen, N. Tokle, and O. Leknes for technical assistance and C. Svensen and S. Diehl for helpful comments on the manuscript. This work was supported by Trondheim Marine Systems Research Infrastructure and by the Norwegian Research Council (contracts 1271767120 and 143184/140).

\section{LITERATURE CITED}

Acuna JL (2001) Pelagic tunicates: why gelatinous? Am Nat 158:100-107

Acuna JL, Anadon R (1992) O. dioica assemblages in a shelf area and their relationship with temperature. J Plankton Res 14:1233-1250

Alldredge AL (1976) Discarded O. dioica houses as sources of food, surface habitats, and particulate organic matter in planktonic environments. Limnol Oceanogr 21:14-23

Behrends G (1996) Long term investigations of seasonal mesozooplankton dynamics in Kiel Bight, Germany. Proc Balt Mar Biol Symp 13:93-98

Castberg T, Larsen A, Sandaa RA, Brussard CPD and 5 others (2001) Microbial population dynamics and diversity during a bloom of the marine coccolithophorid Emiliana huxleyi. Mar Ecol Prog Ser 221:39-46

Cushing DH (1989) A difference in structure between ecosystems in strongly stratified waters and in those that are only weakly stratified. J Plankton Res 11:1-13

Deibel D (1998) The abundance, distribution and ecological impact of doliolids. In: Bone Q (ed) The biology of pelagic tunicates. Oxford University Press, Oxford

Deibel D, Powell CVL (1987) Comparison of the ultrastructure of the food concentrating filter of two O. dioicas. Mar Ecol 
Prog Ser 39:81-85

Fessenden L, Cowles TJ (1994) Copepod predation on phagotrophic ciliates in Oregon coastal waters. Mar Ecol Prog Ser 107:103-111

Flood PR, Deibel D, Morris C (1992) Filtration of colloidal melanin from seawater by planktonic tunicates. Nature 355:630-632

Gifford DJ, Dagg MJ (1991) The microzooplankton-mesozooplankton link: consumption of planktonic Protozoa by the calanoid copepods Acartia tonsa and Neocalanus plumchrus. Mar Microb Food Webs 5:161-177

Gismervik I, Andersen T, Vadstein O (1996) Pelagic food webs and eutrophication of coastal waters: impact of grazers on algal development. Mar Pollut Bull 33:22-35

Hansen PJ, Bjornsen PK, Hansen BW (1997) Zooplankton grazing and growth: scaling within the 2-2000 $\mu \mathrm{m}$ body size range. Limnol Oceanogr 42:687-704

King KR, Hollibaugh JT, Azam F (1980) Predator-prey interactions between the larvacean Oikopleura dioica and bacterioplankton in enclosed water columns. Mar Biol 56:49-57

Kleppel GS (1993) On the diets of calanoid copepods. Mar Ecol Prog Ser 99:183-195

Koshikawa H, Harada S, Watanabe M, Kogure K and 5 others (1999) Influence of plankton community structure on the contribution of bacterial production to metazooplankton in a coastal mesocosm. Mar Ecol Prog Ser 186:31-42

Landry MR, Peterson WK, Fagerness VL (1994) Mesozooplankton grazing in the Southern California Bight. I. Population abundances and gut pigment contents. Mar Ecol Prog Ser 115:55-71

Lippert B (2001) Trophische Interaktionen in einem experimentellen marinen pelagischen Nahrungsnetz. MSc thesis, University of Munich

Nakamura Y (1998) Blooms of tunicates Oikopleura spp. and Dolioletta gugenbauri in the Seto Inland Sea, Japan, during summer. Hydrobiologia 385:183-192

Nejstgaard JC, Gismervik I, Solberg PT (1997) Feeding and reproduction by Calanus finmarchicus and microzooplankton grazing during mesocosm blooms of diatoms and the coccolithophore Emiliana huxleyi. Mar Ecol Prog Ser 147:197-217

Ohtsuka S, Onbe T (1989) Evidence of selective feeding on larvaceans by the pelagic copepod Candacia bipinnata. J Plankton Res 11:869-872

Paffenhöfer GA, Knowles SC (1980) Omnivorousness in marine planktonic copepods. J Plankton Res 2:355-365

Editorial responsibility: Otto Kinne (Editor),

Oldendorf/Luhe, Germany
Perez MT, Dolan JR, Fukai E (1997) Planktonic oligotrich ciliates in the NW Mediterranean: growth rates and consumption by copepods. Mar Ecol Prog Ser 155:89-101

Pierce RW, Turner JT (1995) Ecology of planktonic ciliates in marine food webs. Rev Aquat Sci 6:139-181

Ramberg L (1976) Relations between phytoplankton and environment in two Swedish forest lakes. Scr Limnol Ups 426:1-97

Ryland JS (1964) The feeding of plaice and sand eel larvae in the southern North Sea. J Mar Biol Assoc UK 44:343-364

Shelbourne JE (1962) A predator-prey relationship for plaice larvae feeding on Oikopleura. J Mar Biol Assoc UK 42: $243-252$

Sommer F, Stibor H, Sommer U, Velimirov B (2000) Grazing by mesozooplankton from Kiel Bight, Baltic Sea, on different sized algae and natural seston size fractions. Mar Ecol Prog Ser 199:43-53

Sommer F, Hansen T, Feuchtmayr H, Santer B, Tokle N, Sommer U (2003) Do calanoid copepods suppress appendicularians in the coastal ocean? J Plankton Res 25:869-871

Sommer U, Stibor H (2002) Copepoda-Cladocera-Tunicata: the role of three major mesozooplankton groups in pelagic food webs. Ecol Res 17:161-174

Stibor H, Vadstein O, Diehl S, Gelzleichter A and 9 others (2004) Copepods act as a switch between alternative trophic cascades in marine pelagic food webs. Ecol Lett $7: 321-328$

Stoecker DK, Capuzzo JM (1990) Predation on protozoa - its importance to zooplankton. J Plankton Res 12:891-908

Uye S, Ichino S (1995) Seasonal variations in abundance, size composition, biomass and production rate of Oikopleura dioica in a temperate eutrophic inlet. J Exp Mar Biol Ecol 189:1-11

Vadstein O, Stibor H, Lippert B, Løseth K, Roederer W, SundtHansen L, Olsen Y (2004) Moderate biomass of omnivorous copepods release grazing control of planktonic algae and may cause algal blooms. Mar Ecol Prog Ser 270:199-207

Valentin JL, Monteiro-Ribas WM, Mureb MA, Pessotti E (1987) Sur quelques zooplanctontes abondantes dans l'upwelling de Cabo Frio. J Plankton Res 9:1195-1216

van Marion P (1996) Ecological studies in Hopavagn, a landlocked bay at Agdenes, Sor-Trondelag, Norway. Gunneria 71:1-38

Verity PG, Smetacek V (1996) Organism life cycles, predation, and the structure of marine pelagic ecosystems. Mar Ecol Prog Ser 130:277-293

Submitted: September 23, 2002; Accepted: February 3, 2004 Proofs received from author(s): March 24, 2004 